\title{
A plasmid encoding enzymes for nylon oligomer degradation: nucleotide sequence and analysis of pOAD2
}

\author{
Ko Kato, Kinya Ohtsuki, Yuji Koda, Tohru Maekawa, Tetsuya Yomo, \\ Seiji Negoro and Itaru Urabe
}

Author for correspondence: Seiji Negoro. Tel: +8168797429 . Fax: +8168797448.

Department of

Biotechnology, Osaka

University, 2-1 Yamada-oka,

Suita, Osaka 565, Japan

\begin{abstract}
The entire nucleotide sequence of nylon oligomer degradative plasmid pOAD2 from Flavobacterium sp. K1723T1 was determined. POAD2 comprises 45519 bp, with a $66.6 \mathrm{~mol} \% \mathrm{G}+\mathrm{C}$ content. The precise loci of the four nylon oligomer degradation genes, namely nyIA (6-aminohexanoate-cyclic-dimer hydrolase gene), nylB (6-aminohexanoate-dimer hydrolase), nylB' (a gene having $88 \%$ homology to nylB) and ny/C (endo-type 6-aminohexanoate oligomer hydrolase), and five IS6100 elements were identified on this plasmid. Comparison of the sequence of POAD2 with those in the GenBank and EMBL databases revealed that the deduced amino acid sequences from eight regions of POAD2 had significant similarity with the sequences of gene products such as oppA-F (oligopeptide permeases), ftsX (filamentation temperature sensitive), penDE (isopenicillin $\boldsymbol{N}$-acyltransferase) and rep (plasmid incompatibility). A functional map of pOAD2 is presented.
\end{abstract}

Keywords: nylon oligomer, degradative plasmid, enzyme evolution

\section{INTRODUCTION}

Research on the microbial degradation of xenobiotic compounds produced by chemical industries is not only important for the environmental sciences, but is also interesting with regard to enzyme evolution. We have been studying the degradation of 6-aminohexanoate oligomers (nylon oligomers found as by-products of the nylon-6 industry) by Flavobacterium sp. strains as a model of how micro-organisms have evolved specific enzymes that degrade xenobiotic compounds. Previous biochemical studies have revealed that three enzymes produced by Flavobacterium sp. KI723T1, 6-aminohexanoatecyclic-dimer hydrolase (EI) (Kinoshita et al., 1977), 6aminohexanoate-dimer hydrolase (EII) (Kinoshita et al., 1981), and endo-type 6-aminohexanoate oligomer hydrolase (EIII) (Negoro et al., 1992), are responsible for the degradation of 6-aminohexanoate oligomers. Cloning and sequencing analyses have shown that the $\mathrm{EI}(n y / A)$, EII $(n y l B)$ and EIII $(n y l C)$ genes are located on POAD2, one

\footnotetext{
Abbreviations: El, 6-aminohexanoate-cyclic-dimer hydrolase; Ell, 6aminohexanoate-dimer hydrolase; Elll, endo-type 6-aminohexanoate oligomer hydrolase; NSF, non-stop frame; RS, repeated sequence.

The GenBank/EMBL/DDBJ accession number for the sequence reported in this paper is D26094.
}

of three plasmids harboured by Flavobacterium sp. KI723T1 (Negoro et al., 1980, 1983), and that these genes are encoded by ORFs of 1479 bp (nyl $A), 1176$ bp (nylB) and $1065 \mathrm{bp}(n y l C)$. Enzymes EI (P-EI) and EII (P-EII) in Pseudomonas sp. NK87 (P-nyl $A$ and $\mathrm{P}-n y l B$ genes) are plasmid-encoded (Kanagawa et al., 1989), and the amino acid sequence identities between F-EI and P-EI and between F-EII and P-EII are $99 \%$ and $35 \%$, respectively (Kanagawa et al., 1993; Tsuchiya et al., 1989).

Previous Southern hybridization experiments have revealed the presence of at least two repeated sequences (RS-I and RS-II) on POAD2. The RS-I regions were found at five loci (Negoro et al., 1983). Four of the five RS-Is (RS- $I_{A}, I_{C}, I_{D}$ and $I_{E}$ ) are identical to IS6100 (880 bp) initially found in Mycobacterium fortuitum, while the remaining one $\left(R S-I_{B}\right)$ contains an additional $420 \mathrm{bp}$, which is a repeated portion of the IS 6100 element, at the 3 '-terminus (Kato et al., 1994). RS-II is found at two loci, namely RS- $\mathrm{II}_{\mathrm{A}}$, which contains the $n y l B$ gene, and RS- $\mathrm{II}_{\mathrm{B}}$, which contains the homologous EII' gene $\left(n y / B^{\prime}\right)$ (Okada et al., 1983). The two genes are identical in size and encode peptides of 392 amino acids differing only in 46 residues (Okada et al., 1983).

Although the nucleotide sequences of the $n y l$ genes and IS 6100 have been determined, they comprise only $10 \%$ of 
the total length of pOAD2. In this paper, we describe the nucleotide sequence of $\mathrm{pOAD} 2$, and construct a functional map of the plasmid based on the homology analyses.

\section{METHODS}

Bacterial strains and plasmids. Flavobacterium sp. KI723T1 was used as a strain for preparing pOAD2 (Negoro et al., 1980). Three plasmids which contain HindIII fragments of pOAD2, i.e. pNDH16 (A+D+F fragments), pNDH56 (B+E fragments) and pNDH5 (C fragments), were constructed as previously described using pBR322 as the vector (Negoro et al., 1983) (Fig. 1). Plasmids pBR322 (Bolivar et al., 1977), pBluescript $\mathrm{SK}^{+}$(Stratagene Cloning Systems), M13mp18 and M13mp19 (Yanisch-Perron et al., 1985) were also used as vectors.

DNA manipulations. Plasmid DNA of Eschericbia coli was prepared by the alkaline extraction method (Birnboim \& Doly, 1979) and purified by CsCl-ethidium bromide density-gradient centrifugation (Sambrook et al., 1989). Plasmids of Flavobacterium strains were similarly prepared with some modifications (Negoro et al., 1980). To separate pOAD2 from the other two plasmids (POAD11 and pOAD3) in the KI723T1 strain, the plasmid mixtures obtained by the $\mathrm{CsCl}$-ethidium bromide density-gradient centrifugation were digested with $X b a \mathrm{I}$, and the DNAs were re-fractionated by density-gradient centrifugation. The pOAD2 has no $\mathrm{XbaI}$ site and hence is maintained as covalently closed circular DNA. The other two plasmids are converted to linear fragments after $\mathrm{XbaI}$ digestion. Hybrid plasmids pNDE1 and pNDE2 were constructed as follows: pOAD2 was digested with EcoRI, and the digested samples were subjected to agarose gel $(1 \%, \mathrm{w} / \mathrm{v})$ electrophoresis (Sambrook et al., 1989). The EcoRI-A (24 kb) and -B $(15 \mathrm{~kb})$ fragments were recovered (Fig. 1), and these fragments were cloned into the EcoRI site of pBR322 (Bolivar et al., 1977). Restriction endonuclease digestion, ligation and transformation were done by conventional methods (Sambrook et al., 1989). Recovery of the DNA fragments from the agarose gel was performed by using a Gene Clean kit (Bio101) (Vogelstein \& Gillespie, 1979).

Sequencing strategy. pNDH5, pNDH16 and pNDH56 were used as initial materials for sequencing. Sub-fragments from pNDH5, pNDH16 and pNDH56 were cloned into M13mp18 and M13mp19. To confirm that the inserted DNA fragments were not altered through cloning experiments, pOAD2 from the original KI723T1 strain was first digested with HindIII, and each fragment was analysed by agarose gel electrophoresis. The patterns of various restriction enzyme digestions of the fragments recovered from pOAD2 were confirmed to be the same as those from pNDH plasmids. To sequence the region including the HindIII sites, sub-fragments containing the HindIII site at positions $0 / 45 \cdot 5,13 \cdot 5,14 \cdot 7,16 \cdot 8,28 \cdot 8$ or $37 \cdot 9 \mathrm{~kb}$ were isolated from pNDE1 and pNDE2, and cloned into pBluescriptII. Sequences of both strands of the whole pOAD2 region were determined by the dideoxy chain-termination method (Sanger $e t$ al., 1977). Sequences including terminal regions in sub-fragments overlapped with adjacent sequences.

\section{RESULTS AND DISCUSSION}

\section{Identification of the nucleotide sequence of pOAD2}

The entire sequence of the nylon oligomer degradative plasmid pOAD2 comprised 45519 bp. pOAD2 contained
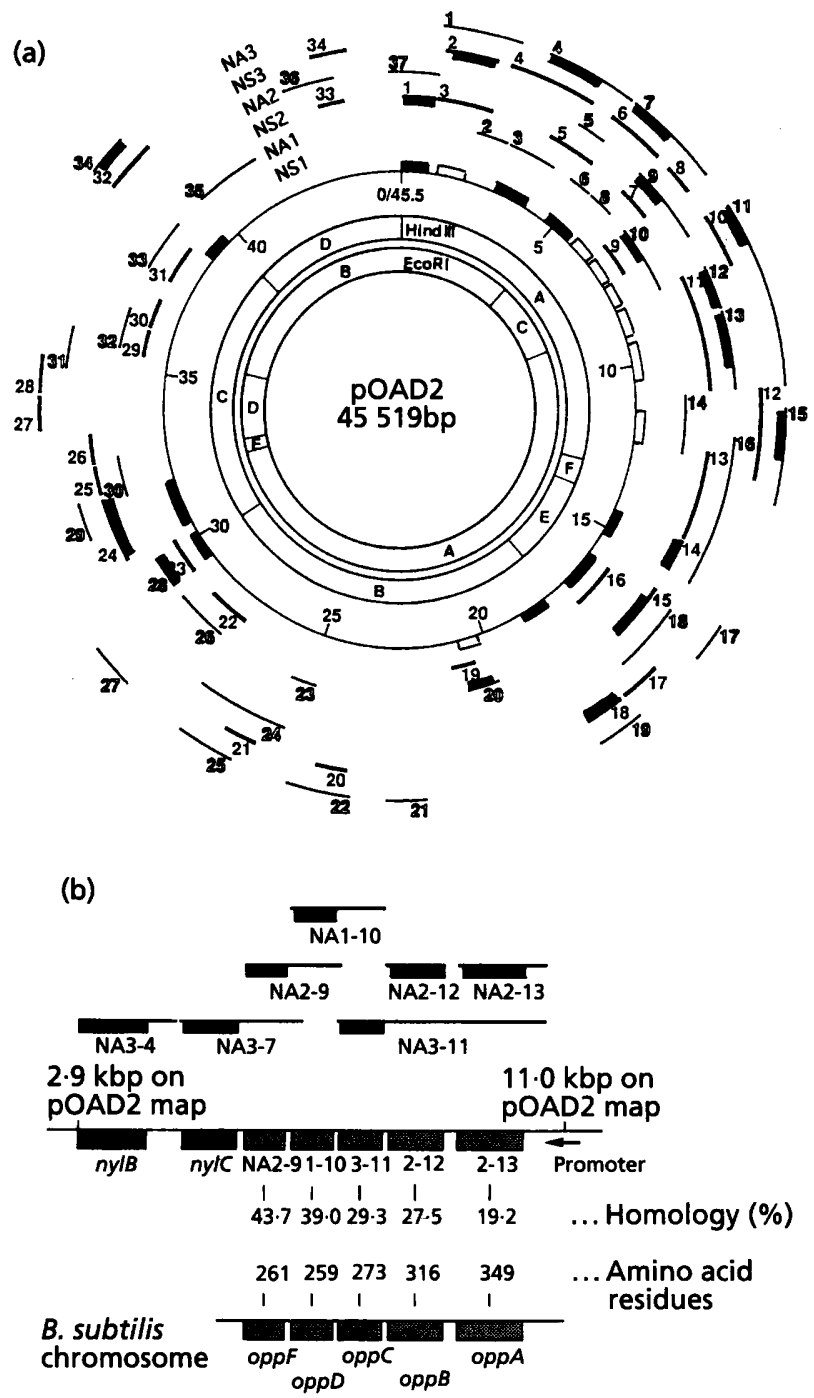

Fig. 1. (a) Location of the NSFs on pOAD2. The three clockwise NSFs (NS1, NS2 and NS3) and three counterclockwise NSFs (NA1, NA2 and NA3) are shown as broken circles. Bold numbers represent the 34 clockwise NSFs and the outlined numbers represent the 37 counterclockwise NSFs. The regions which have significant homology with some proteins registered in the database are shown as heavy boxes. The location of the six HindIII fragments (A-F) and the five EcoRI fragments (A-E) are shown in the closed circles. (b) Location of the seven NSFs in the 2.9-11 kb region of pOAD2. The regions showing homology with the opp gene cluster are shown as heavy boxes (see Fig. 2). The promoter region essential for the expression of the nylB in $E$. coli (Okazaki et al., 1988) is represented by an arrow. Identity between the opp genes and the region on pOAD2 is also shown.

876 termination codons in the three frames of clockwise direction and 778 termination codons in the three frames of counterclockwise direction (Fig. 1). The clockwise strand contained 7108 adenines, 15514 guanines, 14812 cytosines and 8085 thymines. The $\mathrm{G}+\mathrm{C}$ content was $66.6 \%$. The plasmid size was in good agreement with that estimated by electron microscopy or by agarose gel electrophoresis, i.e. $43 \cdot 6 \mathrm{~kb}$ (Negoro et al., 1980). 
Table 1. Identified gene products found on pOAD2

\begin{tabular}{|lclc|}
\hline NSF & $\begin{array}{c}\text { Location of } \\
\text { NSF }\end{array}$ & Identified element or gene & $\begin{array}{c}\text { Location of the gene* } \\
\text { (Init. codon-term. codon) }\end{array}$ \\
\hline NS2-1 & $2-802$ & RS-I $_{\text {A }}$ (IS6100-transposase) & $41-805$ \\
NS2-14 & $14327-15127$ & RS-I $_{\text {B }}$ (IS6100-transposase) & $14366-15130$ \\
NS3-18 & $17871-18671$ & RS-I $_{\text {C }}$ (IS6100-transposase) & $17910-18674$ \\
NA1-28 & $29212-30012$ & RS-I $_{\text {D }}$ (IS6100-transposase) & $29973-29209$ \\
NA3-34 & $38754-39554$ & RS-I (IS6100-transposase) & $39515-38751$ \\
NA3-4 & $2814-4601$ & $n y l B$ (EII) & $3989-2811$ \\
NA3-7 & $4605-6566$ & $n y l C$ (EIII) & $5669-4602$ \\
NS2-15 & $15641-17044$ & $n y l B^{\prime}$ (EII') & $15869-17047$ \\
NS2-24 & $30338-31837$ & $n y l A$ (EI) & $30359-31840$ \\
\hline
\end{tabular}

* Location of the gene indicates the position from the initiation Met codon (init.) to the termination codon (term.).

fIn RS-I $I_{B}$, the 420 bp region at the $3^{\prime}$ terminus (location: 15185-15604) was a repeated portion of the IS 6100 element.

Table 2. Deduced gene product showing significant homology to extant protein

\begin{tabular}{|c|c|c|c|c|c|c|c|}
\hline NSF & $\begin{array}{c}\text { Location of } \\
\text { NSF }\end{array}$ & Gene & Origin & Score* & $\begin{array}{c}\text { Number of } \\
\text { amino acids } \dagger\end{array}$ & $\begin{array}{c}\text { Homology } \\
(\%)\end{array}$ & Reference \\
\hline NA2-9 & $5669-7402$ & $o p p F$ & Bacillus subtilis & $68 \cdot 2$ & 261 & $43 \cdot 7$ & Perego et al. (1991) \\
\hline NA1-10 & $6439-8193$ & $o p p D$ & Bacillus subtilis & $59 \cdot 0$ & 259 & $39 \cdot 0$ & Perego et al. (1991) \\
\hline NA3-11 & $7257-10856$ & $o p p C$ & Bacillus subtilis & $51 \cdot 1$ & 273 & $29 \cdot 3$ & Perego et al. (1991) \\
\hline NA2-12 & $8126-9100$ & $o p p B$ & Bacillus subtilis & $27 \cdot 3$ & 316 & $27 \cdot 5$ & Perego et al. (1991) \\
\hline NA2-13 & $9104-10861$ & $o p p A$ & Bacillus subtilis & $18 \cdot 5$ & 349 & $19 \cdot 2$ & Perego et al. (1991) \\
\hline NS3-2 & $885-1958$ & $f t s X$ & E. coli & $18 \cdot 4$ & 293 & $22 \cdot 2$ & Gill et al. (1986) \\
\hline \multirow[t]{2}{*}{ NA3-15 } & $11259-13058$ & penDE & Aspergillus nidulans & $31 \cdot 8$ & 336 & $27 \cdot 7$ & Tobin et al. (1990) \\
\hline & & & Penicillium chrysogenum & $26 \cdot 7$ & 337 & $26 \cdot 7$ & Tobin et al. (1990) \\
\hline \multirow[t]{4}{*}{ NA1-20 } & $20026-20841$ & $\operatorname{rep} A$ & $\begin{array}{l}\text { Agrobacterium tumefaciens } \\
\text { (pTiB6S3) }\end{array}$ & $20 \cdot 4$ & 173 & $28 \cdot 3$ & Tabata et al. (1989) \\
\hline & & $\operatorname{sop} A$ & E. coli $(\mathrm{F})$ & $17 \cdot 1$ & 254 & $24 \cdot 8$ & Mori et al. (1986) \\
\hline & & $\operatorname{par} A$ & E. coli (P1 phage) & $15 \cdot 5$ & 127 & $33 \cdot 9$ & Davis et al. (1992) \\
\hline & & inc $C$ & E. coli (RK2) & $17 \cdot 1$ & 225 & $28 \cdot 0$ & $\begin{array}{l}\text { Thomas \& Smith } \\
\text { (1986) }\end{array}$ \\
\hline
\end{tabular}

* The level of homology was judged by a statistical method (see text). The score was expressed as the ratio of the homology score in the library of the random sequences to their corresponding SD.

† Numbers of amino acid residues in the homologous region. For NA2-9, 1-10, 3-11, 2-12 and 2-13, regions homologous with Opp proteins are shown in Fig. 2.

\section{Functional map of pOAD2 based on the homology analysis}

The ORF is generally used as a discrete unit for homology searches. However, an ORF is defined by the presence of a major initiation codon (ATG) or some minor initiation codons, such as GTG and TTG, and termination codons (TAA, TAG and TGA). Since this definition may unnecessarily restrict searches for homology, we compared the sequences of POAD2 and those in the database with non-stop frames (NSFs), i.e. coding regions flanked by one termination codon and its successive termination codon on the sequence (Yomo et al., 1992). A data library of amino acid sequences covering the total length of the registered sequences in the sense and antisense strands from the DNA database (GenBank release 71; EMBL release 30 ) was initially constructed. All the amino acid sequences of the $71 \mathrm{NSF}$ found in pOAD2 were then aligned with those in the constructed data library by using the computer program FLAT in DDBJ (Pearson \& Lipman, 1988). Random sequences were first generated from the same amino acid composition of the found NSFs. The level of homology between these random sequences and the selected sequences from the data library was judged by a statistical method (program RDF2 of FLAT in DDBJ) (Pearson \& Lipman, 1988).

Fig. 1 shows the location of NSFs with more than $600 \mathrm{bp}$. 
(a)

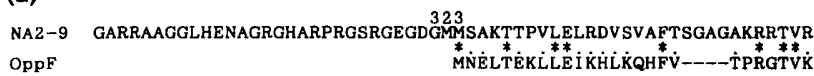

AMNAVTLEVAPGETLGLVGESGSGGTTTASVALGLKRPDSGEVLLLG-SPFTRSRRAN--

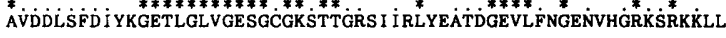

--AGKLQAVLQHPHWSLNPRRKVGESVREPLTVARRDLGRSEQRORVTEMLEQVGLNPAF

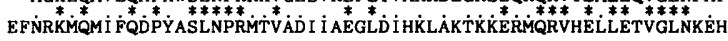
AERYPHELSGGORQRVSVARALVTEPRFI VFDEAVSALDVAVQMQILALIRELQAEHRFG ANRYPHEF SGGQRQRi Ġं ALFI SHDLGAVQRVADRVAVLFRGDLVETAATDEFFRNPRHPYSQTLLERA

(b)

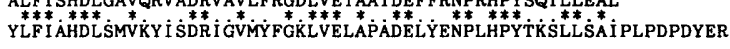
NA1-10 PLHQPHRRHDARSARSARDKEPRMTANAPAAPVVLLTGFSAEYRTRLGVTRALDGIDLDV OppD

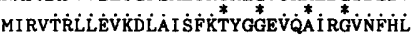

ARGELLAIVGESGSGKSTVSOAIGRMLP-RACHVTSGSVHVLGRDLADLAPDAIRALRRE

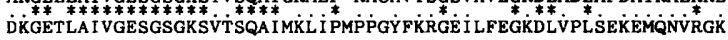
SLGFI PQDPIASLDPTMRI RRQLELAL---RPLGGPVDPGSLAQLLESVRILEPERVLRL

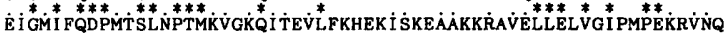

YPHEVSGGMAQRI AIALTMAREPEI ILIADEPTASLDAQVRDEILTLIVDLVQRSGASLIW

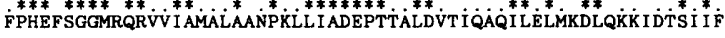
ISHDLGAVRRWCDRVVUMHQGR IVEEGPTARVLDEPRADYTRTLVAAMPGRADLAAKETE

(c)

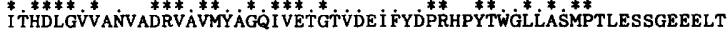

NA3-11 PHHERARPARRRHREGR IMTTYSLPLSKKKKRAVKTRPPRDALFI AAACALGLIVLVAVAA

OPPC MQNI PKNMFEPAAANAGDAEK I SKKSLSL WKं்

AVIP-FAGDPAKI IGTRLSPPSAAYPLGTDALGRSVLARLLEGTRTTLVLSTLAVYCTAV

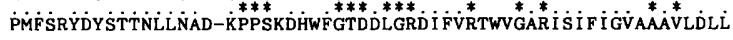

ISUILGL I AGYAGGWAREVIMRLSDVLYSFPS IVLAILI IAAVVGPGQAAVLSS I VLVTVP

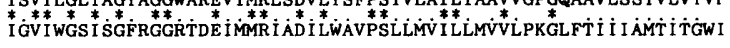

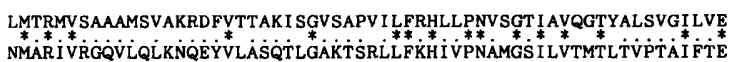
GGLSFLGYGVQPPRSSLGLL IQEGGSYMLQAPWLLF I PAAVLVVAILS INLI I GDTMRDRL

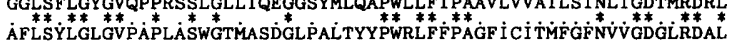
1194
DPRETRSLV

DPKLRK

(d)

NA2-12 FRMMQIL LRWSAGRVMSALITLLGVSVLI IFVAIRLMPGSYED I I LGPLASAEERQLLAEAY

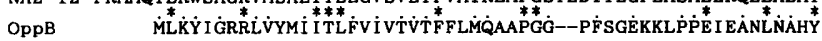

GLNQPIFYQYFAWIGQVLTGELGTSYVTQSSVSGEMLER-I PVTATLTIMAMAVTLLVGY

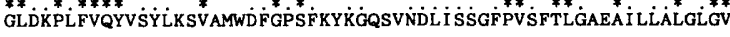
PLGI WTGVRSGAKQGGAVGRVVSS I GI ISPEFFLGSIVI FLFSQFSLGLKVGGGASI GTG

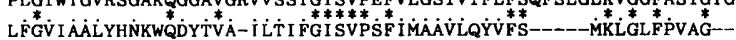

FWPTLGALLLPALVLSVFCVAATARTTRDAVMGVLVEPH I TAAVARGETTRHIVRHHVLR -WDṠWAYYTFLPS

NAGI PILTLLGTI I TAYLLGGAVI I ITLFENLPGLGSFMVTGLGRRDFAVVQATVLFAAAVF

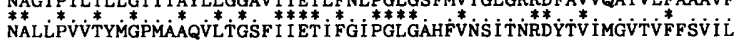
VVLSLVLDLITSALDPRVAVTGKAGS

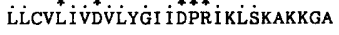

(e)

(e) 204 RA2-13 RALTVDDVVGSLERQVASQSVWSGQMGPVESVEATGDDQVTVKLGSPYAPFLAALANTPA

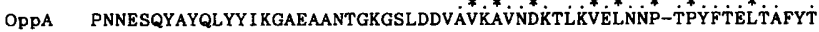

AILPMQEVNDGSVDLTTTM-----LGTGPYLVADHRQDESWTFTANPDWHGGDNLAVQTLE

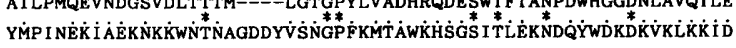
LQIVDQESTRQAALREGS---AGMA-NFVNIDSLSQLGGNEGLQIVKQTQSDLYYVLVNS

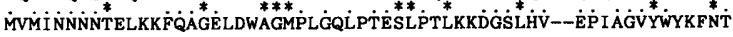
QKPDSPLNDQDVRFAINTAIDRQAIAD IVFAGETTPT-GITPSNLPG--D-C-ACLVD-E

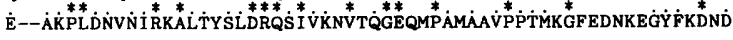

LPSEQAA IEDARATIEETGAGDVELDLIVNTLEPVMAQIAQL VQQQL-AEI IVTVRI I EQV

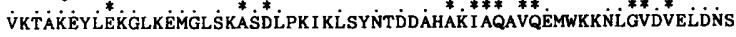

DTATYNERVFSAQPGDFDLS-I SWFAGYSDP-SMVTKWWNPEQAFFNVGFTGVHEDLNA

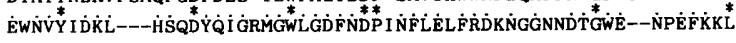
IAEGASETDPDARAEVLTRLCASADEYAEMVPLVHRPSI I GFDTTAVSPTIQSNEGYGN I

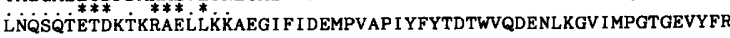

There were 34 NSFs on the three clockwise frames (NS21 to NS3-34) and 37 NSFs on the three counterclockwise frames (NA3-1 to NA2-37). Since almost all pOAD2 regions include at least one NSF, these defined NSFs were therefore used as primary discrete units for the homology search.

Among the 71 NSFs, nine NSFs could be identified as nyl $A$, nylB, nylB ${ }^{\prime}, n y l C$, and five IS6100 elements (Table 1). In addition, there were eight NSFs that had high similarity with sequences in the database (Table 2). The regions having significant similarity in the database were the $o p p$ gene cluster (oligopeptide permease), rep (replication protein), penDE (isopenicillin $N$-acyltransferase) and $f t s X$ (heat-shock response and cell division). The remaining 54 NSFs were found not to have a significant level of similarity with any sequences in the database.

We have reported that the expression of the $n y / B$ gene is controlled by a region approximately $6 \mathrm{~kb}$ away from the nylB gene (Okazaki et al., 1988). Interestingly, within this $6 \mathrm{~kb}$ region, a nylC gene was found upstream. Moreover, by Northern hybridization experiments using the $n y / B$ probe, $7 \mathrm{~kb}$ and $9 \mathrm{~kb}$ mRNA strands were detected (Zhou et al., 1990). Thus, nylB and $n y l C$ seem to constitute an operon with other unknown gene(s) (Zhou et al., 1990). After sequencing pOAD2 and a homology search, we found that in between the promoter region and the nylC gene there is a DNA region homologous to the oligopeptide uptake ( $o p p$ ) gene clusters (Alloing et al., 1990; Hiles et al., 1987; Perego et al., 1991; Rudner et al., 1991). Five of the NSFs (NA2-9, NA1-10, NA3-11, NA2-12 and NA2-13) had significant homology (44-19\%) with the opp genes (Figs $1 \mathrm{~b}$ and 2, Table 2). OppD and OppF have $44.4 \%$ homology. Interestingly, $34 \%$ identity was found between NA2-9 and NA1-10 (Fig. 3). Since the Nterminus of NA2-13 is only $5 \mathrm{bp}$ downstream of the putative -10 region (TACCGT, position 10872-10867), it is likely that these five genes are cotranscribed from this common promoter.

Oligopeptide permease in Bacillus subtilis is considered to constitute a complex of ATPase, inner-membrane protein and binding protein (Perego et al., 1991). OppF and OppD, which have the ATPase activity, are localized in the cytoplasm, while OppB and OppC are membrane proteins. OppA is located on the cell surface and is assumed to be the initial binding site for substrates. Similar systems are also found in Salmonella typhimurium strains (Hiles et al., 1987). Therefore, the low homology between NA2-13 and OppA suggests that divergence between the sequences in OppA may reflect major

Fig. 2. Alignment of amino acid sequences showing the identity between the NSFs and the opp gene cluster. (a) NA2-9 and OppF; (b) NA1-10 and OppD; (c) NA3-11 and OppC; (d) NA2-12 and OppB; (e) NA2-13 and OppA. Amino acids are represented with one-letter codes. Identical amino acids and analogous amino acids are marked by asterisks and dots, respectively. Numbers shown above the sequences indicate the position of the amino acid residues from the $\mathrm{N}$-terminal of the NSF. Gaps are shown as dashes. 
NA2-9 MSAKTTPVLELRDVSVAFTSGAGAKRRTVRAMNAVTLEVAPGETLGLVGESGSGKTT-TA

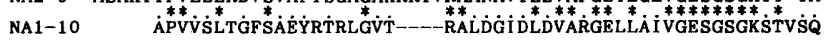
SVALGLKRP---DSGEVLLLGSPFTRSRRANAGKL-QAVLQHPHWSLNPRRKVGESVREP

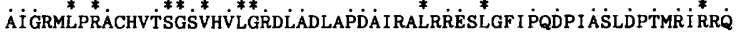
LTVARRDLGRSEQRQRVTEMLEQV-GLNPAFAER-YPHELSGGQRQRVSVARALVTEPRF

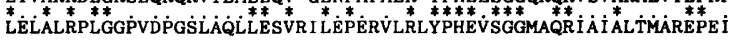

IVFDEAVSALDVAVQMQI LALIRELQAEHRFGALF I SHDLGAVQRVADRVAVLFRGDLVE

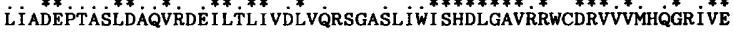

TAATDEFFRNPRHPYSQTLLEAL

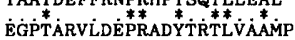

Fig. 3. Alignment of sequences showing identity between NA29 and NA1-10 proteins. The region of NA2-9 homologous with the OppF is aligned with the region of NA1-10 homologous with OppD (see Fig. 2). The identical amino acids and analogous amino acids are marked by asterisks and dots, respectively. Gaps are shown as dashes.

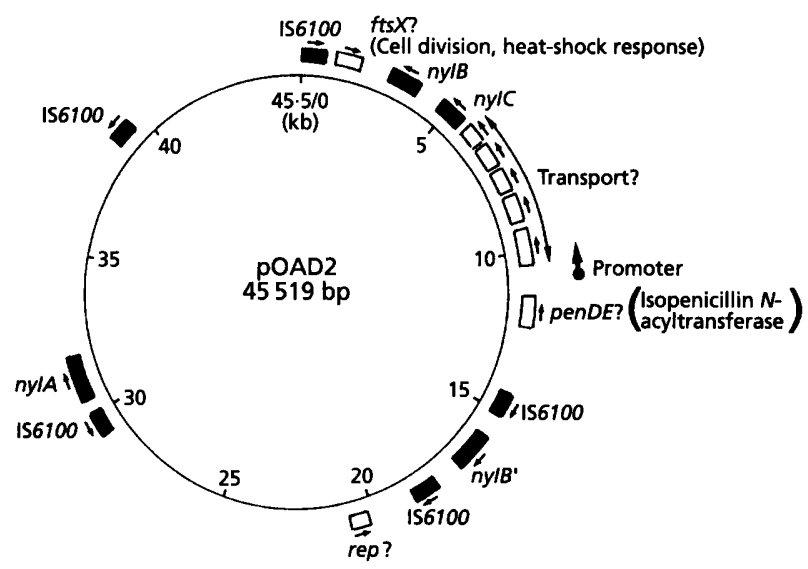

Fig. 4. Deduced functional map of pOAD2. Heavy boxes represent the regions encoding the identified gene products; i.e. four nylon oligomer degradation genes (nylA, nylB, nylB' and $n y / C)$ and 156100 sequences appearing five times on the plasmid. Open boxes represent the DNA regions which have significant homology with the sequences of oppA, oppB, oppC, $\circ p p D$, opp $F, f t s X$, penDE and rep genes. Arrows indicate the direction of gene transcription.

differences in substrate specificity. Since nylon oligomers and oligopeptides are analogous compounds in which monomeric units having an amino group and a carboxy group are combined by amide bonds, the gene clusters on pOAD2 might be involved in the transport of nylon oligomers.

NS3-2 had $22 \cdot 2 \%$ similarity with $f t s X$, which is involved in the heat-shock response and affects cell division in $E$. coli (Gill et al., 1986). The fts $X$ gene constitutes an operon with ftsE (Gill et al., 1986), and ftsE and $o p p D$ have sequence similarity (Gill et al., 1986). NA1-20 was homologous to several genes responsible for plasmid replication, such as repA from Agrobacterium tumefaciens plasmid pTiB6S3 (Tabata et al., 1989), inc C of the broad host range plasmid RK2 (Thomas \& Smith, 1986), $\operatorname{sop} A$ of the E. coli mini-F plasmid (Mori et al., 1986), and par $A$ of E. coli P1 phage (Davis et al., 1992) (Table 2). Since there is no other DNA region which has high similarity to the gene responsible for replication, it is likely that NA120 is responsible for plasmid replication. NA3-15 had $28 \%$ identity to isopenicillin $N$-acyltransferase (penDE) from Aspergillus nidulans and Penicillium cbrysogenum (Alvarez et al., 1993; Tobin et al., 1990).

Fig. 4 illustrates the functional map of pOAD2, though the biological function of most gene products has not yet been confirmed. The precise loci of the nine regions having identified functions (four nyl genes and five IS6100 elements) and the eight regions having significant similarity to the genes registered in databases are shown on the map. However, 54 NSFs remain to be identified, and have no similarity to sequences in the database. As additional sequences are registered in the database, other genes might be identified. The complete nucleotide sequence of this plasmid can serve as the basis for further biochemical, genetical and evolutionary studies on pOAD2, which will lead to a more basic understanding of microbial adaptation towards a xenobiotic compound and of the evolution of new genes such as those responsible for degradation of xenobiotic compounds.

\section{REFERENCES}

Alloing, G., Trombe, M.-C. \& Claverys, J.-P. (1990). The ami locus of the gram-positive bacterium Streptococcus pneumoniae is similar to binding protein-dependent transport operons of gram-negative bacteria. Mol Microbiol 4, 633-644.

Alvarez, E., Meesschaert, B., Montenegro, E., Gutierrez, S., Diez, B., Barredo, J. L. \& Martin, J. F. (1993). The isopenicillin-N acyltransferase and isopenicillin- $\mathrm{N}$ amidohydrolase, 6-aminopenicillanic acid acyltransferase and penicillin amidase activities, all of which are encoded by the single penDE gene. Eur J Biochem 215, 323-332.

Birnboim, H. C. \& Doly, J. (1979). A rapid alkaline extraction procedure for screening recombinant plasmid DNA. Nucleic Acids Res 7, 1513-1523.

Bolivar, F., Rodriguez, R. L., Greene, P. J., Betlach, M. C., Heyneker, H. L., Boyer, H. W., Crosa, J. H. \& Falkow, S. (1977). Construction and characterization of new cloning vehicles. II. A multipurpose cloning system. Gene 2, 95-113.

Davis, M. A., Martin, K. A. \& Austin, S. J. (1992). Biochemical activities of the $\operatorname{par} A$ partition protein of the $\mathrm{P} 1$ plasmid. Mol Microbiol 6, 1141-1147.

Gill, D. R., Hatfull, G. F. \& Salmond, G. P. (1986). A new cell division operon in Escherichia coli. Mol \& Gen Genet 205, 134-145.

Hiles, I. D., Gallagher, M. P., Jamieson, D. J. \& Higgins, C. F. (1987). Molecular characterization of the oligopeptide permease of Salmonella typhimurium. J Mol Biol 195, 125-142.

Kanagawa, K., Negoro, S., Takada, N. \& Okada, H. (1989). Plasmid dependence of Pseudomonas sp. strain NK87 enzymes that degrade 6aminohexanoate-cyclic dimer. J Bacteriol 171, 3181-3186.

Kanagawa, K., Oishi, M., Negoro, S., Urabe, I. \& Okada, H. (1993). Characterization of the 6-aminohexanoate-dimer hydrolase from Pseudomonas sp. NK87. J Gen Microbiol 139, 787-795.

Kato, K., Ohtsuki, K., Mitsuda, H., Yomo, T., Negoro, S. \& Urabe, I. (1994). Insertion sequence IS6100 on plasmid pOAD2, which degrades nylon oligomers. J Bacteriol 176, 1197-1200.

Kinoshita, S., Negoro, S., Muramatsu, M., Bisaria, V. S., Sawada, S. \& Okada, H. (1977). 6-Aminohexanoic acid cyclic dimer 
hydrolase: a new cyclic amide hydrolase produced by Acbromobacter guttatus KI72. Eur J Biochem 80, 489-495.

Kinoshita, S., Terada, T., Taniguchi, T., Takene, Y., Masuda, S., Matsunaga, N. \& Okada, H. (1981). Purification and characterization of 6-aminohexanoic acid oligomer hydrolase of Flavobacterium sp. K172. Eur J Biochem 116, 547-551.

Mori, H., Kondo, A., Ohshima, A., Ogura, T. \& Hiraga, S. (1986). Structure and function of the $F$ plasmid genes essential for partitioning. J Mol Biol 192, 1-15.

Negoro, S., Shinagawa, H., Nakata, A., Kinoshita, S., Hatozaki, T. \& Okada, H. (1980). Plasmid control of 6-aminohexanoic acid cyclic dimer degradation enzymes of Flavobacterium sp. KI72. J Bacteriol 143, 238-245.

Negoro, S., Taniguchi, T., Kanaoka, M., Kimura, H. \& Okada, H. (1983). Plasmid-determined enzymatic degradation of nylon oligomers. J Bacteriol 155, 22-31.

Negoro, S., Kakudo, S., Urabe, I. \& Okada, H. (1992). A new nylon oligomer degradation gene $(n y / C)$ on plasmid pOAD2 of Flavobacterium sp. J Bacteriol 174, 7948-7953.

Okada, H., Negoro, S., Kimura, H. \& Nakamura, S. (1983). Evolutionary adaptation of plasmid-encoded enzymes for degrading nylon oligomers. Nature 306, 203-206.

Okazaki, M., Uemura, T., Nishimori, Y., Wakamatsu, K., Shimosaka, M., Saito, H., Negoro, S. \& Okada, H. (1988). Analysis of a promoter-like region in Flavobacterium which controls 6aminohexanoic acid linear oligomer hydrolase gene expression in Escherichia coli. I Ferment Technol 66, 489-494.

Pearson, W. R. \& Lipman, D. J. (1988). Improved tools for biological sequence analysis. Proc Natl Acad Sci USA 85, 2444-2448.

Perego, M., Higgins, C. F., Pearce, S. R., Gallagher, M. P. \& Hoch, J. A. (1991). The oligopeptide transport system of Bacillus subtilis plays a role in the initiation of sporulation. Mol Microbiol 5, 173-185

Rudner, D. Z., LeDeaux, J. R., Ireton, K. \& Grossman, A. D. (1991). The spoOK locus of Bacillus subtilis is homologous to the oligopeptide permease locus and is required for sporulation and competence. J Bacteriol 173, 1388-1398.
Sambrook, J., Fritsch, E. F. \& Maniatis, T. (1989). Molecular Cloning: a Laboratory Manual, 2nd edn. Cold Spring Harbor, NY: Cold Spring Harbor Laboratory.

Sanger, F., Nicklen, S. \& Coulson, A. R. (1977). DNA sequencing with chain-terminating inhibitors. Proc Natl Acad Sci USA 74, 5463-5467.

Tabata, S., Hooykaas, P. J. \& Oka, A. (1989). Sequence determination and characterization of the replicator region in the tumorinducing plasmid pTiB6S3. J Bacteriol 171, 1665-1672.

Thomas, C. M. \& Smith, C. A. (1986). The $\operatorname{tr} B$ region of broad host range plasmid RK2: the nucleotide sequence reveals inc $C$ and key regulatory gene $\operatorname{tr} B / k o r A / k o r D$ as overlapping genes. Nucleic Acids Res 14, 4453-4469.

Tobin, M. B., Fleming, M. D., Skatrud, P. L. \& Miller, J. R. (1990). Molecular characterization of the acyl-coenzyme A: isopenicillin-N acyltransferase gene (penDE) from Penicillium chrysogenum and Aspergillus nidulans and activity of recombinant enzyme in Escherichia coli. J Bacteriol 172, 5908-5914.

Tsuchiya, K., Fukuyama, S., Kanzaki, N., Kanagawa, K., Negoro, S. \& Okada, H. (1989). High homology between 6-aminohexanoatecyclic-dimer hydrolases of Flavobacterium and Pseudomonas strains. J Bacteriol 171, 3187-3191.

Vogelstein, B. \& Gillespie, D. (1979). Preparative and analytical purification of DNA from agarose. Proc Natl Acad Sci USA 76, 615-619.

Yanisch-Perron, C., Vieira, J. \& Messing, J. (1985). Improved M13 phage cloning vectors and host strains: nucleotide sequences of the M13mp18 and pUC19 vectors. Gene 33, 103-119.

Yomo, T., Urabe, I. \& Okada, H. (1992). No stop codons in the antisense strands of the genes for nylon oligomer degradation. Proc Natl Acad Sci US A 89, 3780-3784.

Zhou, Z. E., Nishimori, Y., Shimosaka, M. \& Okazaki, M. (1990). Transcription of a gene for 6-aminohexanoic acid linear oligomer hydrolase of Flavobacterium sp. KI72 in Escherichia coli. J Ferment Bioeng 70, 266-268.

Received 9 January 1995; revised 26 June 1995; accepted 29 June 1995. 